Article

\title{
Black Soldier Fly School Workshops as Means to Promote Circular Economy and Environmental Awareness
}

\author{
Andreas Walter ${ }^{1, *,+}$, Thomas Klammsteiner ${ }^{2, *,+} \oplus$, Magdalena Gassner ${ }^{3}$, \\ Carina Desirée Heussler ${ }^{2}$, Suzanne Kapelari ${ }^{3}{ }^{\mathbb{D}}$, Markus Schermer ${ }^{4}\left(\mathbb{D}\right.$ and Heribert Insam ${ }^{2}$ (I) \\ 1 Department of Biotechnology \& Food Engineering, MCI-The Entrepreneurial School, Maximilianstraße 2, \\ 6020 Innsbruck, Austria \\ 2 Department of Microbiology, University of Innsbruck, Technikerstraße 25d, 6020 Innsbruck, Austria; \\ carina.heussler@uibk.ac.at (C.D.H.); heribert.insam@uibk.ac.at (H.I.) \\ 3 Department of Subject-Specific Education, University of Innsbruck, Innrain 52d, 6020 Innsbruck, Austria; \\ magdalena.gassner@student.uibk.ac.at (M.G.); suzanne.kapelari@uibk.ac.at (S.K.) \\ 4 Department of Sociology, University of Innsbruck, Universitätsstraße 15, 6020 Innsbruck, Austria; \\ markus.schermer@uibk.ac.at \\ * Correspondence: andreas.walter@mci4me.at (A.W.); thomas.klammsteiner@uibk.ac.at (T.K.); \\ Tel.: +43-512-2070-3823 (A.W.); +43-512-507-51322 (T.K.) \\ + These authors contributed equally to this work.
}

Received: 19 October 2020; Accepted: 14 November 2020; Published: 17 November 2020

\begin{abstract}
Today, insect applications for food and feed are of strong economic, ecological and social interest. Despite their tremendous potential, insects still elicit negative associations in the mindset of Western consumers, which is attributed to a lack of knowledge and scarce opportunities for engagement in this topic. The citizen science project 'six-legged livestock' aims to increase the potential of the insect Hermetia illucens (black soldier fly), merging the topics 'waste re-valorisation' and 'protein production' as a cross-link to circular economy. Workshops were held in four school classes, involving 89 pupils, aged 15 to 18 years old. Making use of organic wastes, participating school classes ran eight rearing systems containing a total of $1800 \mathrm{H}$. illucens larvae. In the four-week experiments, the pupils monitored larval growth and development. Evidently, the pupils were highly motivated to run their rearing systems and fulfil their working tasks. Furthermore, negative associations with insects, including phobia and scepticism decreased, while excitement for the topic increased after hands-on work with the insects. The presented project may be considered an innovative approach paving the way for the establishment of insects as an important educational tool, since they are still underrepresented in scholarly curricula, despite the public outrage over insect decline.
\end{abstract}

Keywords: Hermetia illucens; black soldier fly; insect biotechnology; waste valorisation; citizen science

\section{Introduction}

Today, insect-based substitutes for conventional food and feed are of strong ecological, social and economic interest [1]. Organisations such as the Food and Agriculture Organization (FAO) have proposed a list of benefits and potentials of insect farming, when compared to conventional livestock [2]: (i) Environmental benefits, such as smaller environmental footprint through reduced greenhouse and ammonia emissions, low water requirement and high feed conversion efficiencies. (ii) Health benefits, such as higher concentrations of beneficial fatty acids, rich in fibre and micronutrients, and lower risk of transmitting zoonotic diseases. (iii) Livelihood and social benefits, such as minimal technical or 
capital expenditure required, and harvesting and farming can provide entrepreneurship opportunities for southern hemisphere nations.

However, the consumer's food preference does not solely depend on rational perceptions such as palatability or nutritional and environmental benefits-it is also defined by emotional and cultural dimensions [3] influenced by cultural history, experience, and adaptation [4]. A large number of surveys focusing on European consumers have revealed a low propensity to consume insects (entomophagy) as a meat substitute [5-7] even when insect parts are not visible and the taste is not particularly identifiable. In a Dutch study [8], just around 3\% of participants who tried typical meat-based dishes such as burgers or nuggets made of vegetables and ground larvae of the beetle Alphitobius diaperinus Panzer consumed these dishes again regularly. It seems that insects still carry negative connotations that are 'deeply embedded in the Western psyche' - they are assumed to be 'dirty, disgusting and dangerous' [3]. These associations are spread through Western media in TV shows such as 'Fear Factor' and 'I'm A Celebrity ... Get Me Out Of Here!' where contestants are forced to eat raw insects to advance in the competition and show their daring [9]. In contrast to entomophagy, there is significantly more support to use insects as animal feed: In Belgium, two-thirds of 415 surveyed farmers found it acceptable to use insects for their livestock [10]. In another survey [11], $66 \%$ of consumers considered fly larvae as suitable feedstuff, over $80 \%$ wanted to know more about insects as feed, and $75 \%$ were happy to eat animals raised on an insect-based diet. Thereafter, Dobermann et al. proposed that increased use of insects in animal feed might also have a beneficial influence to strengthen consumer acceptability of entomophagy [9].

Over the last decade, Hermetia illucens L. (Diptera: Stratiomyidae)—the black soldier fly (BSF)—has experienced increasing scientific attention because of its potential to contribute to a circular economy by addressing two environmental concerns, specifically waste management and protein production [12]. H. illucens (Figure 1) is a 13 to $20 \mathrm{~mm}$ long fly in the insect family Stratiomyidae [13] native to the Neotropics but now spread across all zoogeographic regions due to anthropogenic drivers [14]. BSF breeding works all year round in the tropics (and under artificial conditions) but just during the growing season in colder areas [15]. Larvae hatch three to four days after oviposition and develop for approximately 14 days in six larval instars including a prepupal stage [16]. Temperature [17], relative humidity [18], food availability [19], and food composition [20] influence development time. The prepupa uses a hook on its anterior end to pull itself out of its substrate and starts to seek a safe location to complete pupal development [17]. Adults eclose about 14 days after pupation [21].

For use as a protein source, the BSF has advantages over many other insects [22]: BSF larvae (BSFL) are polyphagous and can tolerate a high nutritional heterogeneity in their diet [22]. To date, sustainable recycling of various organic waste, including pig manure [23], fish offal [24], fruits and vegetables [25], palm kernel meal [26] and municipal organic waste [19], were conducted. During degradation, BSFL digest, aerate, and dry organic waste, producing granules of increased $\mathrm{pH}$ and ammonia content [27] that can be used as plant fertilizer [28,29]. Growth rate and body weight of the main product, the BSFL, are coupled to substrate features and environmental parameters (e.g., substrate moisture, relative humidity, temperature, light, larval density, and microbial symbionts) [22]. Larvae are high in protein (37-63\% of dry matter) and fat (7-39\% of dry matter) content with higher concentrations of minerals and medium-chain saturated fatty acids ( $67 \%$ total fatty acids) and lower concentrations of polyunsaturated fatty acids ( $13 \%$ total fatty acids) than other insects used in managed feeding programs [30]. Used either alone or as dietary supplement, they support good growth of poultry [31], swine [32], rainbow trout [24], blue tilapia, and catfish [33]. The emigration of fully-grown BSF prepupae from their food source is another beneficial characteristic: At this stage, the prepupae start to leave their humid habitat. Systems taking advantage of this 'self-harvesting' habit provide ramps as 'escape routes' for prepupae $[24,25,34,35]$ with a collecting container at their end, decreasing the breeding costs by reducing harvesting efforts. During metamorphosis and in their adult stage, BSF source their energy from the larval-based fat body and do not ingest food. Hence, adult BSF do not enter human dwellings and avoid contact with other animals, in contrast to, for example, the housefly 
(Musca domestica L.). Additionally, larvae secrete chemicals that prevent competitors to lay eggs on a food source colonized by BSFL, resulting in effective reduction of, for example, M. domestica [36].

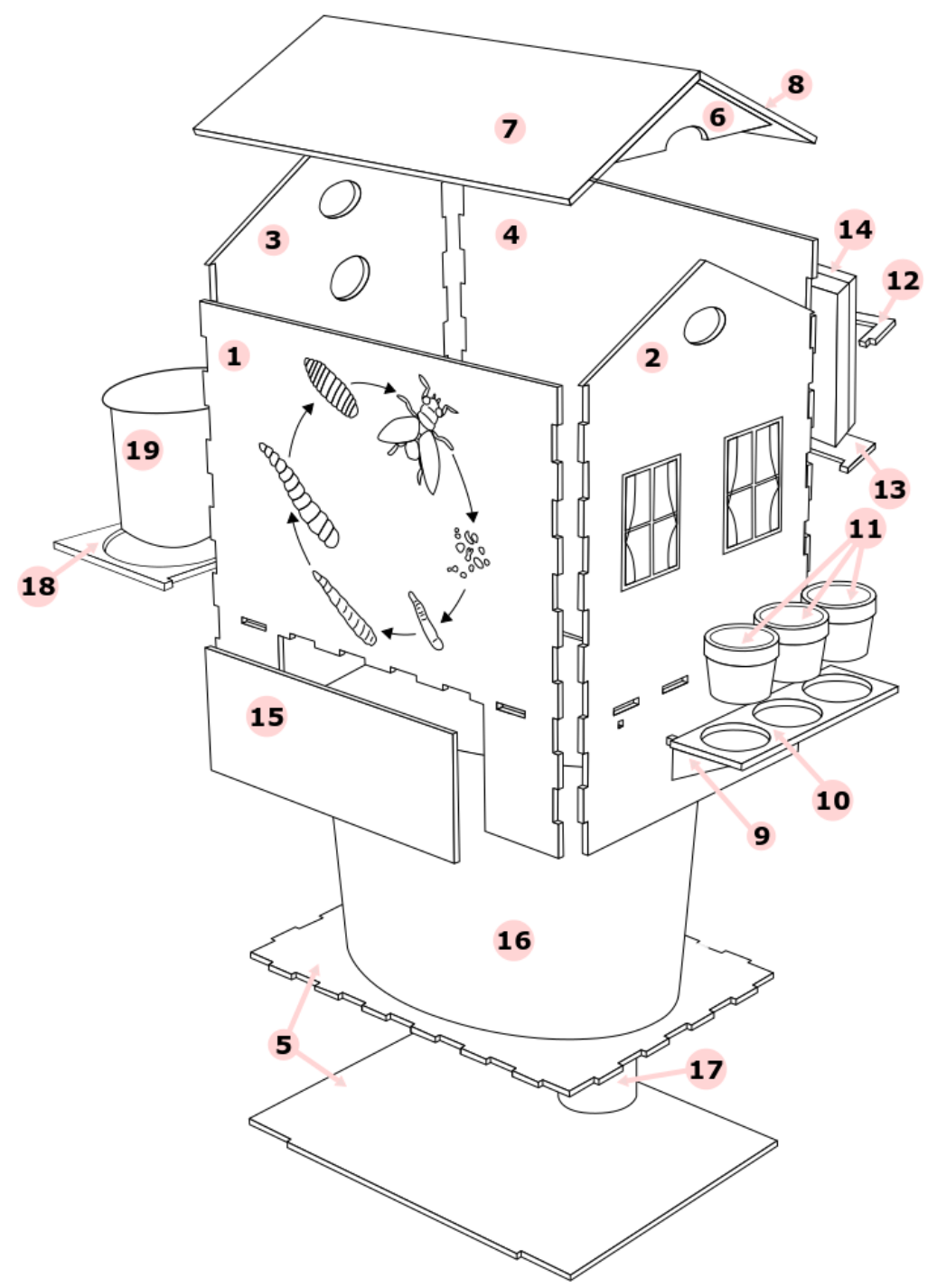

Figure 1. Exploded view of the rearing system for black soldier fly larvae.

In order to increase acceptance in future consumers and their peers, we conceptualized the scientific school project 'A house for the critters' as part of our citizen science project 'Six-legged livestock'. Hands-on workshops with pupils served as means to spread knowledge and raise awareness on $H$. illucens and its potential in circular economy (following the motto 'from waste to feed').

The school project was planned to meet the following demands: (A) The project should follow a straightforward design, and should be easy to adapt to different school types, students' needs, and age groups. (B) All required learning materials should be open access and prepared in a way to be used by non-scientists, and all further resources should be affordable and readily available. (C) Nevertheless, this research project and all embedded experiments should fulfil the principles of good scientific practice. Research was conducted to address the following research questions:

1. Is the provided support sufficient for students to fulfil the required tasks properly?

2. Does participating in the project has an impact on students' attitude towards insects? 


\section{Materials and Methods}

The presented information was kept as simple as possible to allow a quick and direct initiation of the project while still conveying enough background knowledge to grasp the key concept. For the reproduction of the workshop, we recommend following the given instructions in combination with the files available both in the supplementary material and on our project homepage https://fromwastetofeed.wordpress.com/.

1. A complete list of all required materials together with graphical assembly instructions for the parts produced by the laser cutter (Supplementary Materials 1).

2. A 12-page booklet summarizing information on the development of the worldwide food and feedstock market, on 'organic waste and its potential in 'circular economy' and on the biology of H. illucens (Supplementary Materials 2).

3. Vector-based digital drawing interchange format (DXF) files for laser cutting a house-like exterior surrounding the inner plastic container of the BSFL-rearing system (Supplementary Materials 3AB).

4. A pre-formatted laboratory journal for uniform documentation of the experiment (Supplementary Materials 4).

5. Material for working stations: 'Legal situation of insect-based food and feed' and 'The development stages of H. illucens' (Supplementary Materials 5).

\subsection{Design and Assembly of the BSFL Rearing System}

The BSFL rearing system (Figure 1) was designed and manufactured in cooperation with the Spielraum FabLab (Innsbruck, Austria). Vector-based digital plans were created in Rhino 6 (McNeel Europe. Barcelona, Spain) and corresponding DXF files were used in RDworks v.8 (RuiDa Technology Co. Ltd., Shenzhen, China) to laser cut $4 \mathrm{~mm}$ medium-density fibre (MDF) boards on a 100W CO2 laser engraving machine with RECI W2 laser tubes (Guangzhou Amonstar Trade Co., Guangzhou, China). The laser-cut wooden parts were sanded and assembled using a hot glue pistol: Four wall segments (1) to (4)) were fixed on the floor segments (5)). The gable pieces (6) serve to underpin the roof elements (7) and (8)). Smaller parts such as the plant potholder (9) and (10) for plant pots (11), the precision scale (14) attachment (12) and (13) and the drainage access cover (15) were added thereafter. Four round neodymium magnets $(10 \times 2 \mathrm{~mm})$ serve to attach the drainage access cover and allow later removal. A tightly sealable, oval 5.5 litre standard size plastic bucket (11); Wolf Plastics Verpackungen, Leoben, Austria) mounted inside the wooden house served as a rearing container for BSFL and receptacle for the organic kitchen waste. A hole saw and a hot glue pistol were used to modify the bucket as follows: Two vents $(\varnothing=60 \mathrm{~mm})$ were cut into the bucket lid and covered with a fiberglass net (mesh size $2 \times 2 \mathrm{~mm}$ ) to allow air circulation inside.

A plastic ramp cut out from $1 \mathrm{~mm}$ polyvinylchloride was fitted inside the bucket in an angle of approximately $40^{\circ}$ to allow self-harvesting of prepupae. A first hole $(\varnothing=30 \mathrm{~mm})$ drilled into the bottom of the bucket allowed for the drainage and filtering of excess fluids trough a fiberglass net (mesh size $1 \times 1 \mathrm{~mm}$ ) into a plastic receptacle (11); $\varnothing=45 \mathrm{~mm})$. A second hole $(\varnothing=18 \mathrm{~mm})$ was drilled into the bucket at the highest point of the ramp to allow prepupal migration into a cardboard collection cup (18) and (19; $\varnothing=80 \mathrm{~mm}$ ) connected via a flexible polypropylene tube. The screw cap of the plastic receptacle was glued onto the border of the hole on the bottom side of the plastic container. The possibility to dis- and reassemble the rearing units allowed for the re-use of the same materials in multiple workshops and reduced costs and wastes.

\subsection{Workshops at Schools}

The project applied the idea of a student/scientist partnership (SSP) approach wherein students are active participants in a scientific research collaboration between students, teachers, and research scientists [37]. Learners worked with practicing scientists from the Department of Microbiology on an authentic scientific topic and conducted feeding experiments with the BSFL. The introductory 
workshop provided a hands-on approach to explore the context, the subject specific content as well as the scientific process. Students carried out the experiments in the class independently. Each school workshop (Figure 2) was conceptualized to last $250 \mathrm{~min}$ divided into a first part (150 $\mathrm{min}$ ) at the beginning of the school experiment and a second part (100 $\mathrm{min}$ ) upon termination of the feeding experiment. The total time corresponds to five full school lessons in Austria.

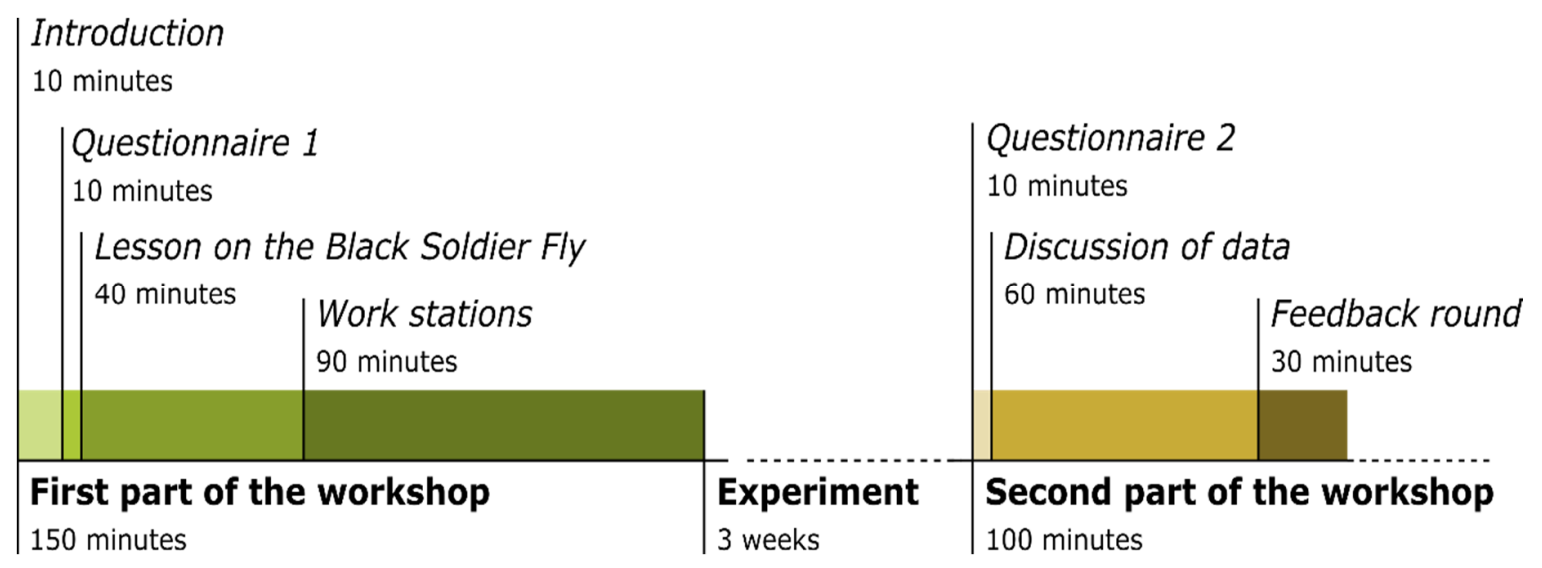

Figure 2. Overview on contents of the student/scientist partnership.

Emphasis was put on group work and the integration of the project into the curriculum of the school classes (e.g., nutrition, resource-management, biodiversity and ecological footprint). Each workshop started with a short introduction of the project team and the project aims (10 min). Preliminary questionnaires (QUE1, Supplementary Materials 6) were distributed and completed within $10 \mathrm{~min}$. Thereafter, the biology of the BSF and the context of its use in waste valorisation was presented (40 $\mathrm{min}$ ) using PowerPoint v. 16.0. (Microsoft, Redmond, WA, USA) slides, self-sticking cardboard figures and a transparent cylinder filled with organic kitchen waste to demonstrate the extent of daily per capita waste production. Booklets containing a compact summary of the project context and the targeted socio-ecological problems were handed out to all participants thereafter. Pupils, randomly split into three groups, rotated through three supervised learning stages scheduled to take $30 \mathrm{~min}$ each (in total $90 \mathrm{~min})$ :

- $\quad$ First stage: Legal framework of insect-based food and feed. Task: Pupils studied reports and worksheets on the legal framework and had to respond to written questions.

- Second stage: The development stages of Hermetia illucens. Task: Pupils used simple incident light microscopes to magnify all stages from egg to adult. Worksheets outlining important morphological traits helped for exact observation.

- Third stage: Methods and set-up of feeding experiments. Task: Briefing on hygienic requirements and good scientific working practice.

Feeding experiments were set up using 200 BSFL, aged 9 to 12 days old, taken from a laboratory BSF colony at the Department of Microbiology (University of Innsbruck, Innsbruck, Austria) maintained as described in Heussler et al. [38]. Participants were advised to feed the larvae with 130 to $260 \mathrm{mg}$ organic waste larva ${ }^{-1} \mathrm{day}^{-1}$. Recommended amounts of feed were based on experiences from previous feeding experiments [25] and feeding events were scheduled three times a week. BSFL rearing systems were operated and monitored by the previously formed groups of pupils and data were recorded in the laboratory journals: Before each feeding event, the first group investigated larval growth by randomly picking and weighting five BSFL on a pocket precision scale (MS-Series professional scale, G \& G $\mathrm{GmbH}, \mathrm{Kaarst}, \mathrm{Germany})$. The second group of pupils fed BSFL with organic wastes. The weight of each component in the heterogenous waste mixture was documented by weighing on the precision scale. The third group observed changes in the rearing environment including residue maturation, 
odour development, and BSFL morphology. After 21-25 days, experiments were terminated when the majority of larvae reached the prepupal stage and started to migrate into the collection cups.

At the beginning of the second workshop, questionnaire 2 (QUE2, Supplementary Materials 6) was handed out and completed (10 min). Thereafter, all BSFL and pupae were counted and weighted again. The collected data on larval growth, environmental changes, and substrate maturation were presented and discussed in class by the groups that took care of the respective tasks (60 min). In a final discussion of $30 \mathrm{~min}$, feedback to improve the workshops and rearing system was gathered.

\subsection{Questionnaire Survey}

Following the sociological definition, we used the term attitude to refer to a "mental position with regard to a fact or state or a feeling or emotion toward a fact or state" [39]. Thus, we assume that attitude towards insects refers to a set of emotions, beliefs, and behaviours when students are confronted with insects. Attitudes are often the result of experience and the sociocultural environment in which a person grows up. Social and educational research has shown that attitudes can have a powerful influence over individuals' behaviour and decision-making and they are both enduring and can also be changed. A pre-post questionnaire survey was conducted to collect information on the students' attitude toward insects and to get insight into whether or not conducting this experiment has the potential to change the students' attitudes. The questionnaire was devised by the authors and followed an inductive approach. The aim was to describe students' attitude development.

\subsection{School Setting}

The project was tested in four school classes ( $\mathrm{C} 1$ to $\mathrm{C} 4$ ) with 26 pupils (17 to 18 years old; one BSF rearing system), 24 pupils (15 to 16 years old; two BSF rearing systems), 19 pupils (16 to 17 years old; one BSF rearing system), and 20 pupils (14 to 15 years old; four BSF rearing systems), respectively. The school (School 1) of C1 and C2 is an educational facility with a more specialised, vocational-oriented curriculum, focusing on tourism, marketing, and management. School classes C3 (School 2) and C4 (School 3) belonged to two distinct schools, with a general, broader, and nonspecific curriculum.

\subsection{Accompanying Research}

To measure the pupil's motivation and willingness to fulfil required work tasks in the feeding experiments, we analysed all laboratory journals and calculated mean and average percentage values. Furthermore, we asked all involved teachers $(n=4)$ for personal feedback at the end of the projects by using a questionnaire (Supplementary Materials 6).

\section{Results}

\subsection{Students Willingness to Fulfil Required Work Tasks}

The introductory workshop and the second part of the workshop were attended by 80 out of 89 pupils (89.9\%), and by 77 out of 89 pupils (86.5\%), respectively. In total, 1800 larvae, 9 to 12 days old, with an average weight of $0.023( \pm 0.009) \mathrm{g} /$ larva were equally distributed to eight BSFL rearing systems and grown on a total amount of $7300 \mathrm{~g}$ kitchen waste, spanning a spectrum of 30 different organic substrates.

The most common organic wastes used were fruits ( $3879 \mathrm{~g} ; 52.6 \%$ ) and fruit peels (1226 g; $16.6 \%)$, followed by vegetables (1115 g; $15.1 \%$ ) and vegetable peels $(271 \mathrm{~g} ; 3.5 \%)$. Grain products such as bread ( $348 \mathrm{~g} ; 4.7 \%)$, coffee grounds ( $256 \mathrm{~g} ; 3.5 \%$ ) and nuts and nut peels $(253 \mathrm{~g} ; 3.4 \%$ ) were also frequently used (Figure 3). 


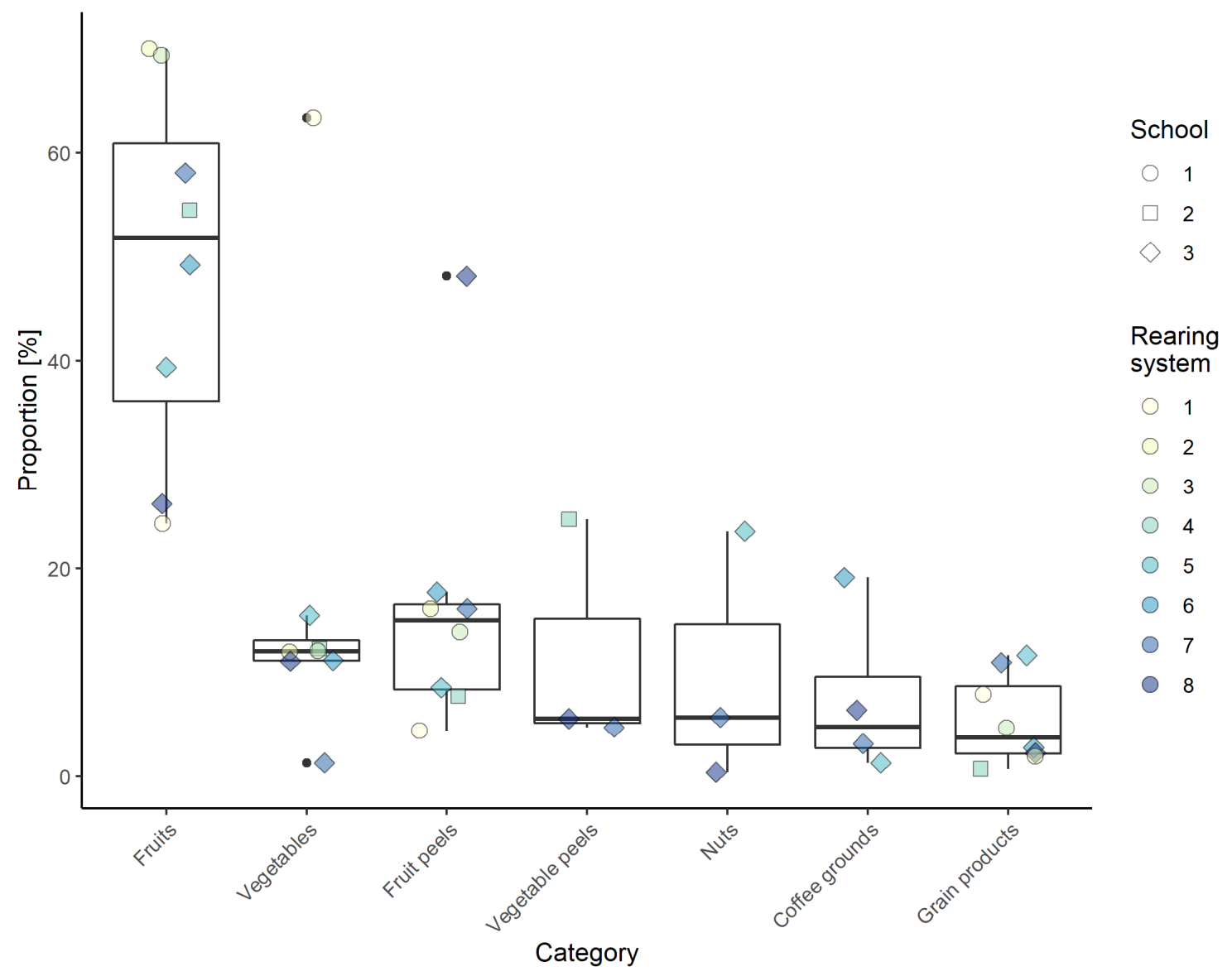

Figure 3. Proportional amounts of various categories of organic wastes used as larval substrate throughout the project. The points indicate the respective fraction of waste category added to each larval rearing station. The data were collected by the pupils from three different types of schools, distributed across four school classes, operating eight larval rearing stations in total.

Measurements from the last sampling events showed that $95.5 \%( \pm 3.6 \%)$ of larvae survived the experimental procedure and reached a fresh weight of $0.22( \pm 0.05) \mathrm{g}_{\text {larvae }}{ }^{-1}$, corresponding to a 10-fold biomass increase (Figure 4). All larvae changed colour from white/cream to dark brown within the last week of the experiments, as documented by the pupils on a colour code table.

Pupils were motivated to complete most scheduled tasks in their experiments. With $91.1 \%( \pm 4.6 \%)$ completeness, the majority of planned feeding events took place and corresponding data was gathered. However, the suggested optimal feeding amounts (130 to $260 \mathrm{mg}_{\text {larva }}{ }^{-1}$ day $^{-1}$ ) were out of range in $37 \%( \pm 18 \%)$ of feeding events, resulting in $10 \%( \pm 8 \%)$ overfeeding and $27 \%( \pm 18 \%)$ underfeeding. Ultimately, in regards of the proposed schedule, larval biomass and substrate/morphological changes were documented with a regularity of $93 \%( \pm 4 \%)$ and $87 \%( \pm 9 \%)$, respectively. 


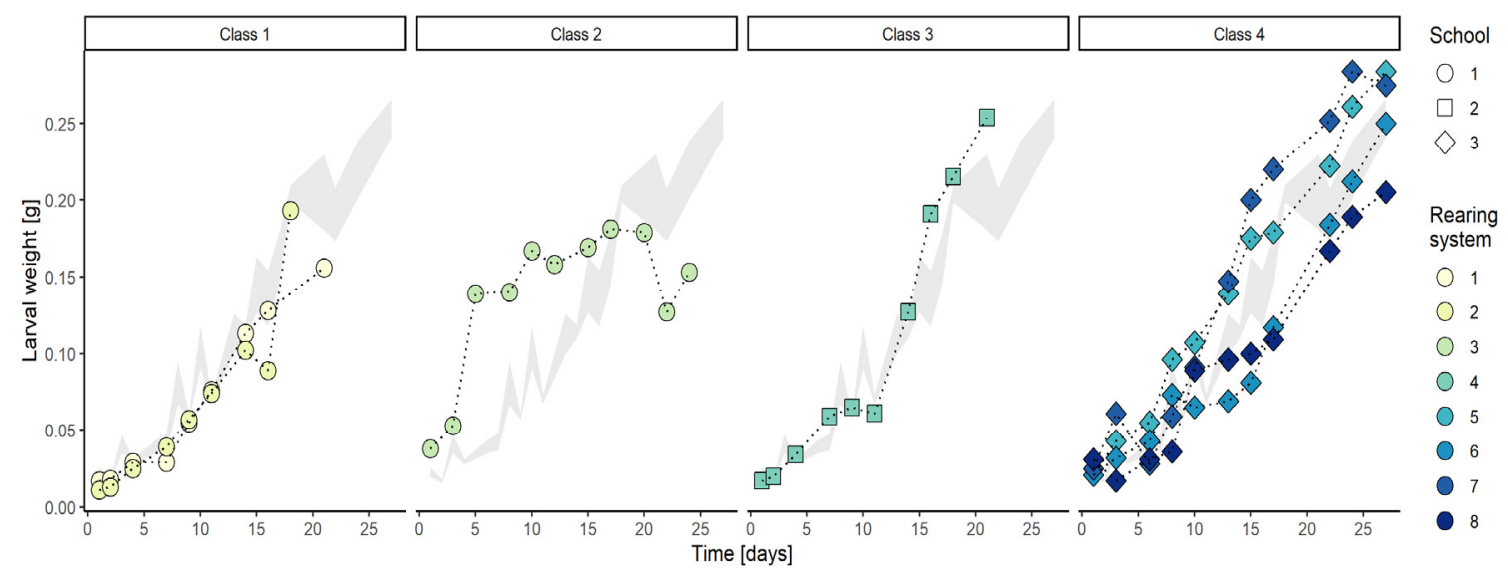

Figure 4. Growth of black soldier fly larvae reared on various organic wastes collected during school breaks. The data were collected by the pupils from three different types of schools, distributed across four school classes, operating eight larval rearing stations in total. The grey ribbons in the background of each facet represent the mean \pm SE calculated from the growth data pooled from all rearing stations $(n=8)$.

\subsection{Students Attitude towards Insects}

At the beginning (QUE1) and at the end (QUE2) of the workshops, participants were asked a set of questions (multiple answers were possible except indicated otherwise). To survey the attitude towards 'insects' and indicate changes in their mindset after the workshops, participants were asked: 'What feelings does the work with the BSF convey? (1.)' In QUE1 $44 \%$ of participants were 'curious', $35 \%$ 'sceptic', 19\% were 'indifferent', 16\% were 'excited', and 13\% 'afraid'. In QUE2 handed out at the end of the project, 'curiosity', 'scepticism', and 'fear' decreased to $26 \%, 28 \%$, and $7 \%$, respectively. 'Indifference' increased to $29 \%$, and 'excitement' to $26 \%$.

Participants were asked, for what applications insects could be used (2.). In QUE1, 'honey' (74\%) followed by 'animal feed' (55\%), 'silk' (45\%) 'human food' (43\%), and 'others' (13\%) were the most frequently chosen answers. The answers changed greatly in QUE2, where 'animal feed' and 'human food' reached $88 \%$ and $55 \%$, respectively. Interestingly, 'honey' decreased by $14 \%$.

Regarding their opinion to use insects as animal feed (3.), $55 \%$ percent of the participants 'never thought' about this, while 30\% found the use of insects as animal feed 'disgusting'. $23 \%$ found it 'good to feed animals with insects'. In QUE2, 29\% still found it 'disgusting' but the frequency of the answer 'never thought about it' decreased by $22 \%$ to $33 \%$ and $44 \%$ (+20\%) found it 'good' to use insects as animal feed.

When the participants were asked if they could imagine eating insects or products made thereof (4.) in QUE1, 49\% could not imagine to eat them, 19\% chose 'yes', and for 39\% entomophagy depends on the offered insect species. In QUE2, participants who could imagine eating insects or products made thereof increased by $10 \%$. The willingness to consume insects was accompanied by an increased importance on the type of offered insect species ('depends on the insect'). This answer was chosen by $53 \%$ of the participants $(+15 \%)$.

Two questions were exclusively prepared for QUE2: When participants were asked what should happen to the larvae after the experiment (5.), 56\% wanted to use them as animal feed, and $47 \%$ chose the option to keep them alive to fulfil their natural life cycle. Other answers, including keeping them alive to repeat the experiment, consuming them as food and freezing them after the experiment were rarely chosen $(16 \%, 4 \%$, and $13 \%$, respectively). In the second question, participants were asked whether or not they spoke with people that were not involved in the experiment about insects and their applications (6.), $39 \%$ chose 'no' while $61 \%$ confirmed. No multiple answers were possible in this question. 


\subsection{Teachers Feedback}

Additionally, teachers were asked for feedback after each school experiment had been completed: For all teachers the workshop was a great success. The opportunity to practice applied science at school and introducing industrially reared insects as topic was well-received. Moreover, establishing the link to food/feedstuff production and treatment of organic wastes in the context of circular economy provided additional benefit by overlapping to multiple school subjects. While the project easily fits the schools' curricula, the most common suggestion for improvement was to extend the debriefing part of the project to allow for a more in-depth processing of the results. Further extension of the background information could generate a deeper understanding of the topic.

\section{Discussion}

The use of insects as an educational tool was proposed in previous studies, because it could offer a wide array of investigations [40-42]. Insects are excellent model organisms because they can often be collected locally, they are inexpensive to purchase and maintain, and they generally have short life cycles. Morphologically distinct developmental stages generated by metamorphosis represent interesting opportunities for observations. Limited time and funds available to teachers support the suitability of insects as research organisms in schools while at the same time involving fewer ethical concerns than others, such as vertebrate animals, would [41]. Although the significance of insects in ecosystem services and for biotechnological approaches (e.g., pollination, honey, and silk) is undisputed, insects are still rarely used in scholarly curricula. A study by Cinici revealed a wide range of misconceptions about life cycle and life forms of the butterfly when she tested 194 children from the ninth to eleventh grade and 14 to 16 years of age in Erzurum, Turkey, by open-ended questions and drawing methods [43]. These misconceptions could be attributed to the results of the pupils' naive experiences and/or insufficient emphasis of the biology curriculum on the phenomenon of metamorphosis. In the study 'Bugs, butterflies, and spiders: Children's understandings about insects', Shepardson collected data from 120 children from kindergarten through fifth-grade in the USA [44]. He found that student ideas about insects reflect their understanding not just based on physical insect characteristics, but also human-insect interactions. Schlegel et al. proposed the significance of local flagship species to promote nature studies in schools [45]. A cohort of 363 children, predominantly aged 10 to 12 years, were asked about their attitudes towards 18 invertebrate species indigenous to Switzerland, including 14 insects. The authors proposed that 'there is a place for insects as local flagship species and especially that there is room for insects other than butterflies'. They suggested working with local species that play an important ecological role, that are easily identifiable and provide a novelty aspect to pupils. In the study of Breuer et al., 246 children aged 9-13 completed a standard questionnaire regarding their attitudes towards 18 invertebrates indigenous to Switzerland. The results indicated that fear and disgust are separate emotions that could be overcome through promoting environmental education programs, especially if they allowed for personal experience and provided information in emotion-activating formats [46].

This conceptualised school project represents a further milestone on the way to establish insects as an important educational tool. The pedagogical methods were in line with the guidelines of Brewer and Smith [47] including (i) hands-on learning, (ii) project-based learning, and (iii) course-based research. Thematically, this project merges the topics 'insects' and 'waste utilisation', specifically 'waste re-valorization' as cross-link to circular economy and the concept of 'from waste to feed'. In doing so, this project perfectly covers the aims of the FAO to 'educate consumers on the benefits of entomophagy' and to 'promote insects as a supplement to feed' [2].

We were able to show that participating pupils were highly motivated to run their BSFL rearing systems and fulfil the majority of the working tasks. The well-tailored workload and duration of the feeding experiments was defined in consultation with teaching personnel; it was, however, limited by the fast growth rates of BSFL. The clearly identifiable morphological changes in larvae over time kept motivation at a high level, a problem usually occurring in long-lasting school projects such as school 
aquariums or school gardens (teacher, personnel communication). Negative associations, such as 'fear' and 'scepticism' decreased after working with BSFL, and 'excitement' was found to be increased. Although 'disgust' was unalterably present at the end of feeding experiments, it was most likely due to the unpleasant (olfactory) characteristics of a highly active biodegradation-process taking place within an enclosed space. However, the responsibility transferred to the pupils and their inquisitiveness to monitor the development of their 'own' larvae was overruling this negative association. Furthermore, the concept of upcycling organics into animal feedstuff, and its potential in terms of efficiency and sustainability was fully understood and supported by most of the pupils. Even the willingness to try entomophagy increased, however, just for selected species. Unsurprisingly, BSFL grown on organic waste were not accepted as a food product.

The BSFL rearing system designed for this study has proven itself as sustainable, low-maintenance, and easily reproducible option for similar feeding experiments. Moreover, the larval biomass output was comparable with results reported from other studies using organic food wastes (Figure 4; [19,48,49]). By avoiding the accumulation of excess liquid especially during early larval development while at the same time providing enough aeriation through the vents, larval activity was promoted without leading to the desiccation of the substrate. For future workshops, we suggest running the rearing units preferably outdoors or in dedicated biology laboratories. Larval activity in combination with elevated temperatures could further promote microbial activity taking place during the degradation of organic wastes and cause malodours. To promote prepupal migration, we suggest a wetting of the substrate with tap water of the organic wastes used in the final feeding event before experiments are terminated, since pupation occurs at dry, safe sides [24,34]. Furthermore, an additional school lesson at the end of the workshop would support pupils in summarizing the great amount of data they collected. Creating figures, calculating basic descriptive statistics, and presenting and discussing their results could add additional interdisciplinary value to the workshops.

\section{Conclusions}

Both teachers and pupils showed great enthusiasm to participate in this highly interactive project that provided means to independently work on potential solutions to current socio-ecological problems on a small scale. The hands-on experimental design promoted teamwork and research experiences. The aim to raise awareness of the potentials and perspectives of the BSF was achieved. This project was conceptualised to meet the interests of 15 to 18 years old, however presented content may be adapted to other age groups at one's own discretion. Despite the potential of university-based projects to enrich scholarly education, more emphasis should be set to 'train-the-trainers'. Here, to raise the teachers' attention for entomology and the potential of insects as an educational tool.

Supplementary Materials: The following are available online at http://www.mdpi.com/2071-1050/12/22/9574/s1.

Author Contributions: Conceptualization, T.K., A.W., M.G., C.D.H., S.K. and M.S.; methodology, T.K. and C.D.H.; validation, A.W., T.K. and C.D.H.; investigation, M.G.; resources, H.I.; writing-original draft preparation, A.W. and T.K.; writing - review and editing, C.D.H., S.K., M.S. and H.I.; visualization, T.K.; supervision, T.K., A.W., C.D.H. and S.K.; project administration, T.K.; funding acquisition, T.K., A.W. and H.I. All authors have read and agreed to the published version of the manuscript.

Funding: This research was funded by the AUSTRIAN SCIENCE FUND (FWF), grant number TCS 48 and the TIROLER WISSENSCHAFTSFÖRDERUNG under grant ‘Gefördert aus Mitteln des Landes Tirol'.

Acknowledgments: We would like to thank Pamela Vrabl for establishing contacts with stakeholders, and all motivated teachers and pupils, who were willed to participle in this school project. Moreover, thanks go to Heinrich Pan (Spielraum FabLab, Innsbruck, Austria), who assisted in designing and manufacturing the BSFL rearing units.

Conflicts of Interest: The authors declare no conflict of interest. 


\section{References}

1. Cerritos, R. Insects as food: An ecological, social and economical approach. CAB Rev. Perspect. Agric. Vet. Sci. Nutr. Nat. Resour. 2009, 4,1-10. [CrossRef]

2. Halloran, A.; Vantomme, P. The Contribution of Insects to Food Security, Livelihoods and the Environment; FAO: Rome, Italy; Available online: http://www.fao.org/forestry/edibleinsects/en/ (accessed on 1 March 2015).

3. Looy, H.; Dunkel, F.V.; Wood, J.R. How then shall we eat? Insect-eating attitudes and sustainable foodways. Agric. Hum. Values 2014, 31, 131-141. [CrossRef]

4. Van Huis, A.; Dicke, M.; Van Loon, J.J.A. Insects to feed the world. J. Insects Food Feed 2015, 1, 3-5. [CrossRef]

5. Mancini, S.; Sogari, G.; Menozzi, D.; Nuvoloni, R.; Torracca, B.; Moruzzo, R.; Paci, G. Factors predicting the intention of eating an insect-based product. Foods 2019, 8, 270. [CrossRef]

6. Megido, R.C.; Gierts, C.; Blecker, C.; Brostaux, Y.; Haubruge, É.; Alabi, T.; Francis, F. Consumer acceptance of insect-based alternative meat products in Western countries. Food Qual. Prefer. 2016, 52, 237-243. [CrossRef]

7. Tan, H.S.G.; House, J. Consumer acceptance of insects as food: Integrating psychological and socio-cultural perspectives. In Edible Insects in Sustainable Food Systems; Springer International Publishing: Berlin, Germany, 2018; pp. 375-386.

8. House, J. Consumer acceptance of insect-based foods in the Netherlands: Academic and commercial implications. Appetite 2016, 107, 47-58. [CrossRef]

9. Dobermann, D.; Swift, J.A.; Field, L.M. Opportunities and hurdles of edible insects for food and feed. Nutr. Bull. 2017, 42, 293-308. [CrossRef]

10. Verbeke, W.; Spranghers, T.; De Clercq, P.; De Smet, S.; Sas, B.; Eeckhout, M. Insects in animal feed: Acceptance and its determinants among farmers, agriculture sector stakeholders and citizens. Anim. Feed Sci. Technol. 2015, 204, 72-87. [CrossRef]

11. Proteinsect. PROteINSECT-Enabling the Exploitation of Insects as a Sustainable Source of Protein for Animal Feed and Human Nutrition. Available online: http://www.proteinsect.eu/ (accessed on 1 March 2015).

12. Nguyen, T.T.X.; Tomberlin, J.K.; Vanlaerhoven, S. Ability of black soldier fly (Diptera: Stratiomyidae) larvae to recycle food waste. Environ. Entomol. 2015, 44, 406-410. [CrossRef]

13. May, B.M. The occurrence in New Zealand and the life-history of the soldier fly Hermetia illucens (L.)(Diptera: Stratiomyidae). N. Z. J. Sci. 1961, 4, 55-65.

14. Marshall, S.A.; Woodley, N.E.; Hauser, M. The historical spread of the Black Soldier Fly, Hermetia illucens (L.)(Diptera, Stratiomyidae, Hermetiinae), and its establishment in Canada. J. Entomol. Soc. Ont. 2015, 146, 51-54.

15. Sheppard, D.C.; Newton, G.L.; Thompson, S.A.; Savage, S. A value added manure management system using the black soldier fly. Bioresour. Technol. 1994, 50, 275-279. [CrossRef]

16. Sheppard, D.C.; Tomberlin, J.K.; Joyce, J.A.; Kiser, B.C.; Sumner, S.M. Rearing methods for the black soldier fly (Diptera: Stratiomyidae). J. Med. Entomol. 2002, 39, 695-698. [CrossRef] [PubMed]

17. Tomberlin, J.K.; Adler, P.H.; Myers, H.M. Development of the black soldier fly (Diptera: Stratiomyidae) in relation to temperature. Environ. Entomol. 2009, 38, 930-934. [CrossRef] [PubMed]

18. Holmes, L.A.; Vanlaerhoven, S.L.; Tomberlin, J.K. Relative humidity effects on the life history of Hermetia illucens (Diptera: Stratiomyidae). Environ. Entomol. 2012, 41, 971-978. [CrossRef]

19. Diener, S.; Zurbrügg, C.; Tockner, K. Conversion of organic material by black soldier fly larvae: Establishing optimal feeding rates. Waste Manag. Res. 2009, 27, 603-610. [CrossRef]

20. Gobbi, P.; Martinez-Sanchez, A.; Rojo, S. The effects of larval diet on adult life-history traits of the black soldier fly, Hermetia illucens (Diptera: Stratiomyidae). Eur. J. Entomol. 2013, 110, 461. [CrossRef]

21. Tomberlin, J.K.; Sheppard, D.C. Factors influencing mating and oviposition of black soldier flies (Diptera: Stratiomyidae) in a colony. J. Entomol. Sci. 2002, 37, 345-352. [CrossRef]

22. Barragan-Fonseca, K.B.; Dicke, M.; Van Loon, J.J.A. Nutritional value of the black soldier fly (Hermetia illucens L.) and its suitability as animal feed-A review. J. Insects Food Feed 2017, 3, 105-120. [CrossRef]

23. Zhu, F.-X.; Wang, W.-P.; Hong, C.-L.; Feng, M.-G.; Xue, Z.-Y.; Chen, X.-Y.; Yao, Y.-L.; Yu, M. Rapid production of maggots as feed supplement and organic fertilizer by the two-stage composting of pig manure. Bioresour. Technol. 2012, 116, 485-491. [CrossRef] 
24. St-Hilaire, S.; Cranfill, K.; McGuire, M.A.; Mosley, E.E.; Tomberlin, J.K.; Newton, L.; Sealey, W.; Sheppard, C.; Irving, S. Fish offal recycling by the black soldier fly produces a foodstuff high in omega-3 fatty acids. J. World Aquac. Soc. 2007, 38, 309-313. [CrossRef]

25. Klammsteiner, T.; Walter, A.; Bogataj, T.; Heussler, C.D.; Stres, B.; Steiner, F.M.; Schlick-Steiner, B.C.; Arthofer, W.; Insam, H. The core gut microbiome of Black Soldier Fly (Hermetia illucens) larvae raised on low-bioburden diets. Front. Microbiol. 2020, 11, 993. [CrossRef] [PubMed]

26. Hem, S.; Toure, S.; Sagbla, C.; Legendre, M. Bioconversion of palm kernel meal for aquaculture: Experiences from the forest region (Republic of Guinea). Afr. J. Biotechnol. 2008, 7, 1192-1198.

27. Kováčik, P.; Kozánek, M.; Taká, P.; Galliková, M.; Varga, L. The effect of pig manure fermented by larvae of house flies on the yield parameters of sunflowers (Helianthus annus L.). Acta Univ. Agric. Silvic. Mendel. Brun. 2014, 58, 147-154.

28. Choi, Y.-C.; Choi, J.-Y.; Kim, J.-G.; Kim, M.-S.; Kim, W.-T.; Park, K.-H.; Bae, S.-W.; Jeong, G.-S. Potential usage of food waste as a natural fertilizer after digestion by Hermetia illucens (Diptera: Stratiomyidae). Int. J. Indust. Entomol. 2009, 19, 171-174.

29. Klammsteiner, T.; Turan, V.; Juárez, M.F.-D.; Oberegger, S.; Insam, H. Suitability of Black Soldier Fly Frass as Soil Amendment and Implication for Organic Waste Hygienization. Agronomy 2020, 10, 1578. [CrossRef]

30. Dierenfeld, E.S.; King, J. Digestibility and mineral availability of Phoenix worms, Hermetia illucens, ingested by mountain chicken frogs, Leptodactylus fallax. J. Herpetol. Med. Surg. 2008, 18, 100-105. [CrossRef]

31. Hale, O.M. Dried Hermetia illucens larvae (Diptera: Stratiomyidae) as a feed additive for poultry. Ga. Entomol. Soc. J. 1973, 8, 16-20.

32. Newton, G.L.; Booram, C.V.; Barker, R.W.; Hale, O.M. Dried Hermetia illucens larvae meal as a supplement for swine. J. Anim. Sci. 1977, 44, 395-400. [CrossRef]

33. Bondari, K.; Sheppard, D.C. Soldier fly larvae as feed in commercial fish production. Aquaculture 1981, 24, 103-109. [CrossRef]

34. Newton, G.L.; Sheppard, D.C.; Watson, D.W.; Burtle, G.J.; Dove, C.R.; Tomberlin, J.K.; Thelen, E.E. The black soldier fly, Hermetia illucens, as a manure management/resource recovery tool. In Proceedings of the State of the Science, Animal Manure and Waste Management, San Antonio, TX, USA, 5-7 January 2005.

35. Klammsteiner, T.; Walter, A.; Pan, H.; Gassner, M.; Heussler, C.D.; Schermer, M.; Insam, H. On Everyone's lips: Insects for food and feed. In Proceedings of the 5th Austrian Citizen Science Conference 2019 (ACSC2019), Obergurgl, Austria, 26 June 2019; SISSA Medialab: Trieste, Italy, 2020; Volume 366, p. 006.

36. Bradley, S.W.; Sheppard, D.C. House fly oviposition inhibition by larvae of Hermetia illucens, the black soldier fly. J. Chem. Ecol. 1984, 10, 853-859. [CrossRef] [PubMed]

37. Sadler, T.D.; Burgin, S.; McKinney, L.; Ponjuan, L. Learning science through research apprenticeships: A critical review of the literature. J. Res. Sci. Teach. Off. J. Natl. Assoc. Res. Sci. Teach. 2010, 47, 235-256. [CrossRef]

38. Heussler, C.D.; Walter, A.; Oberkofler, H.; Insam, H.; Arthofer, W.; Schlick-Steiner, B.C.; Steiner, F.M. Influence of three artificial light sources on oviposition and half-life of the Black Soldier Fly, Hermetia illucens (Diptera: Stratiomyidae): Improving small-scale indoor rearing. PLoS ONE 2018, 13, e0197896. [CrossRef] [PubMed]

39. Chaiklin, H. Attitudes, behavior, and social practice. J. Soc. Soc. Welf. 2011, 38, 31.

40. Matthews, R.W.; Flage, L.R.; Matthews, J.R. Insects as teaching tools in primary and secondary education. Annu. Rev. Entomol. 1997, 42, 269-289. [CrossRef]

41. Golick, D.A.; Heng-Moss, T.M. Insects as educational tools: An online course teaching the use of insects as instructional tools. Am. Entomol. 2013, 59, 183-187. [CrossRef]

42. Ernst, C.; Vinke, K.; Giberson, D.; Buddle, C.M. Insects in education: Creating tolerance for some of the world's smallest citizens. Manag. Insects Recreat. Tour. 2013, 289-305.

43. Cinici, A. From caterpillar to butterfly: A window for looking into students' ideas about life cycle and life forms of insects. J. Biol. Educ. 2013, 47, 84-95. [CrossRef]

44. Shepardson, D.P. Bugs, butterflies, and spiders: Children's understandings about insects. Int. J. Sci. Educ. 2002, 24, 627-643. [CrossRef]

45. Schlegel, J.; Breuer, G.; Rupf, R. Local insects as flagship species to promote nature conservation? A survey among primary school children on their attitudes toward invertebrates. Anthrozoös 2015, 28, 229-245. 
46. Breuer, G.B.; Schlegel, J.; Kauf, P.; Rupf, R. The Importance of Being Colorful and Able to Fly: Interpretation and implications of children's statements on selected insects and other invertebrates. Int. J. Sci. Educ. 2015, 37, 2664-2687. [CrossRef]

47. Brewer, C.A.; Smith, D. Vision and Change in Undergraduate Biology Education: A Call to Action; American Association for the Advancement of Science: Washington, DC, USA, 2011.

48. Čičková, H.; Newton, G.L.; Lacy, R.C.; Kozánek, M. The use of fly larvae for organic waste treatment. Waste Manag. 2015, 35, 68-80. [CrossRef] [PubMed]

49. Liu, Z.; Minor, M.; Morel, P.C.H.; Najar-Rodriguez, A.J. Bioconversion of three organic wastes by black soldier fly (Diptera: Stratiomyidae) larvae. Environ. Entomol. 2018, 47, 1609-1617. [CrossRef] [PubMed]

Publisher's Note: MDPI stays neutral with regard to jurisdictional claims in published maps and institutional affiliations.

(C) 2020 by the authors. Licensee MDPI, Basel, Switzerland. This article is an open access article distributed under the terms and conditions of the Creative Commons Attribution (CC BY) license (http://creativecommons.org/licenses/by/4.0/). 